\title{
Patriarchy in the Selected Works Sherzad Hasan; The Fortress and my Father's Dogs, A Woman on a Minaret and The Plain of the Slaughtered Gazelles
}

\section{Diyar Jamal Mohammed}

Department of English, Faculty of Languages, University of Sulaimani, Sulaimani, Kurdistan Region, Iraq

englishwdiyar@gmail.com

\section{ARTICLE INFO}

\section{Article History:}

Received: 4/8/2021

Accepted: 16/9/2021

Published: Autumn 2021

Keywords: Sherzad

Hasan, Patriarchy,

Feminism, Culture,

Religion.

Doi:

10.25212/Ifu.qzj.6.4.36
ABSTRACT (1951 or 1952-present) addresses patriarchy in his novels and novellas. Many Islamic thinkers try to distance and purify Islam from the unpleasant attributes that existed in culture, Arabic culture particularly. Therefore, Islamic researchers call for better readings and understandings of the Qur'an especially regarding the issues of patriarchy and feminism as for them patriarchy is rooted in the cultures and not the teachings of Islam. Although Hasan acknowledges that men do exploit religion for their interests, nonetheless he intertwines both the culture and Islam together and blames them all together for the patriarchal state of the Kurdish society. Through this perspective, Hasan's works conflate Islam with culture and critically question the results of their effects on the gender roles in the Kurdish society. A selected reading of Hasan's works shows how patriarchy is engraved in Kurdish culture by the forces of the common understandings of religion, Islam specifically. Hasan is one of the Kurdish thought pillars addressing patriarchy and its grave consequences, gender inequalities, and freedom.

\section{Introduction}

It can be said that patriarchy is rooted in the majority of the world's cultures. Because of the differences in cultures around the world, differences in understandings of gender roles exist. It is no secret that Western people consider the cultures in the 


\section{QALAAI ZANISTSCIENTIFIC JOURNAL \\ A Scientific Quarterly Refereed Journal Issued by Lebanese French University - Erbil, Kurdistan, Iraq \\ Vol. (6), No (4), Autumn 2021 \\ ISSN 2518-6566 (Online) - ISSN 2518-6558 (Print)}

middle east as regressive, patriarchal, and anti-feminist and this is blamed on the ironfist of religion, Islam in particular. Many researchers try to combat this view and urge Westerners to differentiate between culture and Islam; they say that it is wrong to vilify an entire religion and blame it for practices that were ever-present in the cultures of the region, the Arabic culture to be specific. Those researchers say that Islam itself came to free women to an extent and gave women rights that were never seen before. However, Sherzad Hasan, born in 1952, does not consider the possibility of religion giving women their freedom; he equally shows religion and the culture that came with it from the "desert" in a bad light and draws the miseries attached to them in his works. Hasan is an unconventional Kurdish writer; while other writers may avoid blaming Islam for patriarchy and the state of women to not face the wrath of the Muslim-dominated society, he comes and does exactly that.

\section{Literature Review}

\subsection{Defining Patriarchy}

As a term, the word Patriarchy comes from the word Patriarch which means father; the term Patriarchy thus means the rule of the father. According to Kamla Bhasin (2006, p.10), the word patriarchy originally meant a big accommodation where women, children, younger men, and slaves were living under the rule of a tyrant older male who oppressed everyone under his rule. However, nowadays the word's meaning has changed and is used as a concept, to mean any system in which the female serves as the subordinate to the male.

The Radical feminists of the second wave of feminism are attributed as the force that made patriarchy to be in the debate of feminists and Kate Millet was the one who championed this effort. Millet in Sexual Politics asserted that patriarchy is when women get dominated by men in every walk of life; not only this, she said that it is still patriarchy when older men dominate younger men. This was very important as it made it clear that patriarchy is related to both sex and age. Heidi Hartmann in The Unhappy Marriage of Marxism and Feminism uniquely describes patriarchy and says that the social bond that men have amongst each other makes them depend on and support one another which leads to domination and alienation of women. Christine Delphy in The Main Enemy focuses on the unfairness of the marriage institution. She 


\section{QALAAI ZANISTSCIENTIFIC JOURNAL \\ A Scientific Quarterly Refereed Journal Issued by Lebanese French University - Erbil, Kurdistan, Iraq \\ Vol. (6), No (4), Autumn 2021 \\ ISSN 2518-6566 (Online) - ISSN 2518-6558 (Print)}

is convinced that the whole system and dynamic of marriage is created by men to entice and control women. Sylvia Walby in Theorizing Patriarchy as a sociallystructured system. According to Walby in this system men are free to do anything they desire; they oppress and dominate women and use them however they want to (Murray 2005, p.97).

\subsection{Origins of Patriarchy}

Concerning patriarchy and its origins, one can see a similar debate to whether gender is social or biological. In many traditional explanations, patriarchy is something normal and it is related to the dominant nature of males. For those traditional thinkers, patriarchy cannot be reversed as it is natural for men to take control and rule. This idea conforms to the understanding that gender is biological; when one is born as a male, he would be inheriting all the adjectives like a strong, dominant, leader; while as a female one would be considered weak, subordinate, soft, etc. This concept of biologically male or female was refuted by Simone de Beauvoir in The Second Sex. She asserted that gender is socially constructed and there is no such thing as biological gender (Lorber 2010, pp.1-20).

Aristotle had the idea that women are there to do whatever men order them to do. He asserted that a man must rule; it is the nature of man to dominate. For Aristotle men are biologically stronger while women are weaker. His assertion for the weakness of women was not only their physicality; for him, women could not think properly or reason. This inability of women to reason was enough for them to be dominated by men. Aristotle went as far as saying that women do not have souls and they are mutilated (Lerner 1986). So based on the ideas of Aristotle about the gender roles, there is no such thing as the creation of patriarchy; patriarchy is natural and is not something that can be reversed. Even a great psychologist like Freud (1977) believed in the supremacy of men and believed that man is the normal being and not a woman.

On the other hand, many theories push the idea of patriarchy being man-made and created historically. Frederick Engels in The Origins of the Family, Private Property and the State (Engels 1940) asserts that the emergence of private property was the main reason and beginning of the subordination of women. Engels believed that men had 


\section{QALAAI ZANISTSCIENTIFIC JOURNAL \\ A Scientific Quarterly Refereed Journal Issued by Lebanese French University - Erbil, Kurdistan, Iraq \\ Vol. (6), No (4), Autumn 2021 \\ ISSN 2518-6566 (Online) - ISSN 2518-6558 (Print)}

a desire to control property and inherit it to the younger generation of men. Thus, women needed to be dominated and subordinated, hence the idea of monogamous marriage came into being and the system of Patriarchy was set.

For Radical feminists, patriarchy is not natural also and they agree with Engels; however, they disagree with him on patriarchy being linked with private property. Radical feminists believe that the source of patriarchy is within the clash between the two sexes and not economic class warfare. Social feminists arise and use Marxism as a principle but they do make the necessary changes so it becomes more applicable for them. Social feminists believe that patriarchy came into being historically as a result of the changes in production modes and it can be reversed (Tong 2018). Hartmann (1981, pp.366-394) asserts that Capitalism made it possible for men everywhere to relate to each other thus the system of patriarchy could cover the whole world. When women work in a capitalist system their work benefits that system and patriarchy too. Through controlling women's work, men can subordinate and dominate women.

\subsection{Middle Eastern and Kurdish Patriarchy}

In the Middle East, the cultures still revolve around men, in many countries, the families follow the Sharia laws, and terrorism and extremism all contribute to the subordination of women. However, it must be noted that the levels of patriarchy differ from one country or one culture to the other. Many Westerners, including feminists, have considered Islam to be essentially oppressive toward women, influenced by their perception of life under fundamentalist, theocratic governments. Many Westerners, for example, view images of women in burqas and mentally apply these expectations to all Muslim women in all Muslim-dominant countries. Although there are many Muslim-predominant countries with varying degrees and interpretations of religious and cultural enforcement, it is a widespread belief in the West that women in these countries are inherently oppressed.

This is where Sherzad Hassan comes into play; in many of his works and interviews, he blames the culture of Islam and the Arabs which came and invaded the Kurdish land. When one reads his works, one learns that it is a grave mistake to consider the Kurdish people as another culture contributing to patriarchy in the Middle East; the 


\section{QALAAI ZANISTSCIENTIFIC JOURNAL \\ A Scientific Quarterly Refereed Journal Issued by Lebanese French University - Erbil, Kurdistan, Iraq \\ Vol. (6), No (4), Autumn 2021 \\ ISSN 2518-6566 (Online) - ISSN 2518-6558 (Print)}

Kurdish culture may have been patriarchal but the invasion of Islam and Arabs made it worse "...it is clear to me that the Arabic and Islamic culture has brought tens of prohibitions, even if we had them in our culture, they accentuated them even more" (Qadir 2002, p.16). Hasan acknowledges that men in patriarchy go against the freedom that God gave Adam and Eve to commit sin, nonetheless he does not concede that religion in its entirety is a massive influence on patriarchy "Religious people go against their own God, as God gave the freedom to Adam and Eve to commit their sin....but some men try to be God and prevent us from committing that same $\sin . . . "$ (Qadir 2002, p.22)

\section{Analysis}

In his novella The Fortress and my Father's Dogs for instance Hasan directly links traditional acts like female genital mutilation (FGM) to patriarchy and religion. For instance, the protagonist, who is his father's oldest son, narrates how terrifying it was to see FGM performed on his sisters and half-sisters. In the line "...our old and merciless mother would hold and stare for a moment at the small pieces of meat and then she throws them to my father's big dogs..." (Hasan 1996, p.18) Hasan illustrates the idea that women themselves become accomplices in the heinous acts performed against the younger generation. This line also shows how FGM is performed under supervision of the father as his hungry dogs are around to frighten any young girl from escaping. On the next page, the boy tells his mother that she should not have performed FGM on his sisters and half-sisters; however, the mother angrily replies with "Boy, you don't know anything about the Sharia law and women's business..." this conveys the direct link between FGM and religion, specifically Islam. The mother acts as a mouthpiece for the patriarch of the house, as if she is programed by him to say all the right things in favor of patriarchy.

On the next few pages, we learn that the man has so many wives and children that he forgets some of their names. The patriarch of the house goes out of the stronghold and always comes back with a new wife. On page 21 one of the wives confronts the patriarch about him getting new wives every time he goes somewhere, and the man yells saying "Why shouldn't I marry? I'm young, I'm able, and the fortress can dwell hundreds more...You idiots, don't you know how important children are? Do you 


\section{QALAAI ZANISTSCIENTIFIC JOURNAL \\ A Scientific Quarterly Refereed Journal Issued by Lebanese French University - Erbil, Kurdistan, Iraq \\ Vol. (6), No (4), Autumn 2021 \\ ISSN 2518-6566 (Online) - ISSN 2518-6558 (Print)}

know how many wives Solomon and Abraham had?" and when his wife says that Solomon and Abraham were prophets, he replies with "...every man is a prophet in his fortress" (Hasan 1996). This idea of comparing one's self to a prophet reiterates the idea that we discussed in the literature review in which Hasan says some men want to play God so they can control women and other young men and prevent them from doing things they desire. This idea of a man being able to marry more than one woman is although related to Islam, but having many more than just 4 as it is implied in the novel goes against even religion. So, one may see how culture may even supersede religion and men through their greed to practice power they go against God's boundaries too.

Another idea that one sees on the pages of this novella and which reiterates radical feminists' perception of the institution of marriage is that the man marries the women for children and when any of the women cannot conceive, he would immediately divorce them. On page 22 (Hasan 1996) the father says "A woman wo cannot conceive is similar to a barren tree, you have to cut it as soon as possible". This shows how dominant men are in patriarchy as they have total control over the institution of marriage. The woman has no say; either give birth or get divorced.

Hasan $(1996$, p.25) continues to tie religion with the tyrannical acts of men in patriarchal societies. This time he shows how extreme beating of one's children, especially the young girls, is an act blessed by God himself. The narrator tells us how the father beat his young sister and locked her in the basement and warned them that no one should release her till she perishes. The young girl got the beatdown just because one night at midnight she went on the roof to breathe fresh air and dance. The father's justification for beating his children so mercilessly is "...it was not in vain that 'Smail' offered his neck to his father Abraham's sword...". Here the father uses the shorter version of Ismail or Ishmail's name as 'smail' in Kurdish is sometimes used as a derogatory name. This speech of him again comparing himself to a prophet and berating another prophet shows how patriarchs see themselves as superior beings and also giving themselves a shield against criticism and resistance. By doing this, patriarchy created an environment when women go against anything men say it would be like going against religion and God, hence they would become infidels who deserve to die. 


\section{QALAAI ZANISTSCIENTIFIC JOURNAL \\ A Scientific Quarterly Refereed Journal Issued by Lebanese French University - Erbil, Kurdistan, Iraq \\ Vol. (6), No (4), Autumn 2021 \\ ISSN 2518-6566 (Online) - ISSN 2518-6558 (Print)}

In this novella, Hasan clearly refers to the mischiefs and oppression of women by the patriarchy. He shows these concerns to be specifically facing Kurdish Muslim women living in the strongholds of men. There is abundance of references to tribal patriarchy also throughout the novel which shows that Hasan wants to present female reproduction and children, FGM, and marriage as issues not only concerning religion but the rotten traditions that glorifies men. Throughout the novella Hasan shows how women perpetuate many of the violence in the family, as he wants to illustrate how deep-rooted and effective religion and tradition are in submitting women to the wills of men.

In his novella $A$ Woman on a Minaret (2011) Hasan writes about a woman who has nothing and no one except a room in which its only view is an old minaret. A minaret is a tall tower that has a balcony and is attached to a mosque from which people are called to prayer. This old minaret being the only view of the woman works as a foreshadowing of the dominance of religion and tradition on women. Hasan tells us "...every morning when she wakes up, she thinks about seeing the minaret...", the minaret being a representative of religion, one sees how invasive it is in the life of the woman. Here, as was the case in the first novel we discussed, Hasan tells us how men with their thirst for power and control they even ignore God or gods. He says "...the blood-thirsty men from the desert came on their horses and destroyed every temple and kidnapped all the gods..." (p.10), by saying 'men from the desert' Hasan clearly mean Arabic Muslim men when they came and fought the Kurds. So, one sees how men established their rule with the power of religion and how women, represented by the lonely woman, being the main victim.

In this novella Hasan draws back on the idea of marriage being an institution by men, for men to suppress and dominate women. Hasan (2011) tells us a background of the lonely woman and we learn that she was forced to marry at a very young age to an old and powerful man. One sees this theme of forced marriages a lot in Hasan's writings as he wants to convey the idea of how devastating this act is towards women. One learns that the old man is a respected man in the society ".... when he came into the house everyone without exception stood up..." also "...he held in his big hands a set of big green prayer beads..." (p.23), so not only he is respected but he is religious as well. Here Hasan tells us that this old scary man 'big hands' marrying a very young 


\section{QALAAI ZANISTSCIENTIFIC JOURNAL \\ A Scientific Quarterly Refereed Journal Issued by Lebanese French University - Erbil, Kurdistan, Iraq \\ Vol. (6), No (4), Autumn 2021 \\ ISSN 2518-6566 (Online) - ISSN 2518-6558 (Print)}

woman is not only blessed by the society, but is also blessed by religion. Again, this theme of tying religion with patriarchy is repeated and reinforced.

The third publication of Sherzad Hasan that will be examined for the theme of patriarchy is titled The Plain of the Slaughtered Gazelles which was published in 1996. This novel talks about the fatal consequences of love in a patriarchal society. One learns about two lovers who ran away from their families in order to be together. They were chased down by forty merciless men;
"...after one night of their escape, forty men with big mustaches have chased them down and before the two lovers reach their destination, they were caught and immediately killed so they become examples for other young boys and girls" (p.10).

Describing the men as having big mustaches is a reference to patriarchy and how menacing the men are in the society. More importantly, however, is that the assembly is dominated by men. Since the society is dominated by men through patriarchy, the big mustaches and their powerfulness are what the speaker notices in narrating the experience that the two lovers had.

One reads that the protagonist of the novel allows his wife to work as a cleaner at the aristocrats' houses. A religious man comes and warns the protagonist about this and tells him not to let his wife work there as she may be used for things other than cleaning. When the husband says he trusts his wife, the religious man says "My son, if what you're saying is right, then the prophets, the companions, and good men wouldn't have had their wives imprisoned inside" (Hasan 1996, p.15). So, here the idea of suppressing women directly correlates to religion. The idea is that even in the society some men give a bit of freedom to their wives, religious people through their sacred stories try to infringe those freedoms. Imprisoning women in their houses is a brutal act of patriarchy but men legitimize it by saying 'God's prophets did it so you should too'. Again, men act like God to say what women can or cannot do. 


\section{QALAAI ZANISTSCIENTIFIC JOURNAL \\ A Scientific Quarterly Refereed Journal Issued by Lebanese French University - Erbil, Kurdistan, Iraq \\ Vol. (6), No (4), Autumn 2021 \\ ISSN 2518-6566 (Online) - ISSN 2518-6558 (Print)}

\section{Conclusion}

Ultimately, Sherzad Hasan's novels give insight into the perspective of Kurdish women which goes against the notion that some Muslim academics want to convey in that religion, especially Islam, is not related to patriarchy. Hasan ties religion and patriarchy and blames them both for the subordination of women. Although Hasan concedes that men through their own understanding and interpretation of religion try to further strengthen their stronghold over women.

The abundance of imagery and references work as a smooth style for Hasan to masterfully tell the stories of women and the tremendous pressures of tradition and religion. Hasan not only gives a voice to the voiceless women; he makes the reader understand them too. He conveys the idea that the Kurdish society, although tribal and traditional, it was the 'Arabic religious zealots came and reinforced patriarchy to the point of suffocation. Hasan eventually presents Kurdish women as victims of religion and patriarchy and through the reprogramming used by men, women became as unwilling and/or unaware participants in the subordination process of the younger generation of women.

\section{References:}

Bhasin, K. (2006). What is patriarchy? Women unlimited. New Delhi.

Murray, Mary. (2005). The law of the father: Patriarchy in the transition from feudalism to capitalism. Routledge.

Lorber, Judith. (2010). Feminisms and their contributions to gender equality." Gender Inequality: Feminist Theories and Politics. 1-20.

Lerner, Gerda. (1986). The creation of patriarchy. USA: Oxford University Press, Vol. 1.

Freud, S. (1977). Freud on Sexuality.

Tong, Rosemarie. Feminist Thought, Student Economy Edition: A More Comprehensive Introduction. Routledge, 2018.

Hartmann, H. I. (1981). The family as the locus of gender, class, and political struggle: The example of housework. Signs: Journal of Women in Culture and Society, 6(3), 366-394.

Qadir, H. (2002). A Conversation with Sherzad Hasan. Stockholm. 


\section{QALAAI ZANISTSCIENTIFIC JOURNAL}

A Scientific Quarterly Refereed Journal Issued by Lebanese French University - Erbil, Kurdistan, Iraq

Vol. (6), No (4), Autumn 2021

ISSN 2518-6566 (Online) - ISSN 2518-6558 (Print)

Hasan, Sh. (1996). The Fortress and my Father's Dogs.

Hasan, Sh. (2011). A Woman on a Minaret.

Hasan, Sh. (1996). The Plain of the Slaughtered Gazelles.

\section{يياوسالارى له جهند نوسينيّكى شيّرزاد حه سهن حهسار و سهگكانى باوكم، زنيّك بهسهر منارهوه و يِيدهشتى كارمامزه كوزراوهكان}

لهم ئارتيكلّهدا بابهتى يِياو سالارى له جهند رِوّمان وكورته رِومانيّكى نوسهرى كورد شيّرزاد حهسهن

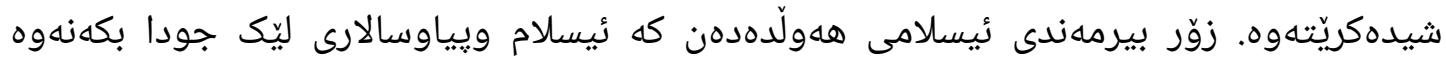

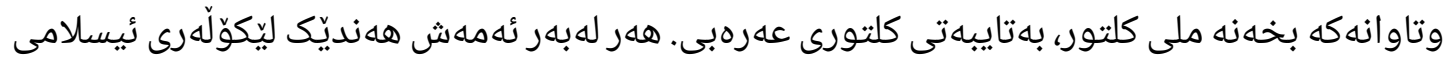

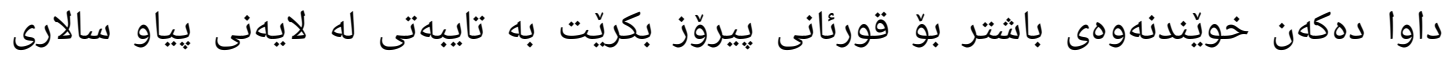

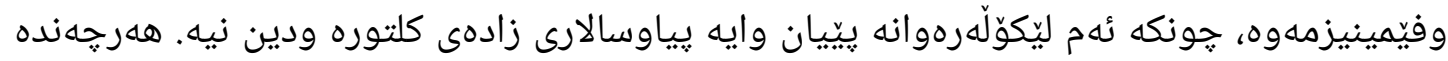







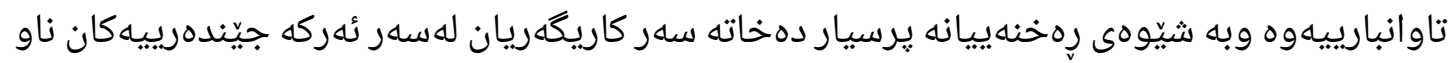

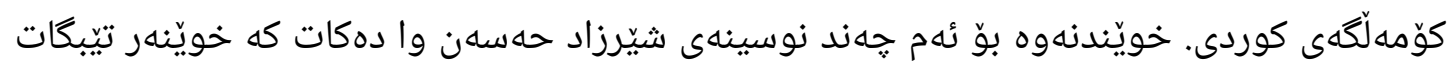

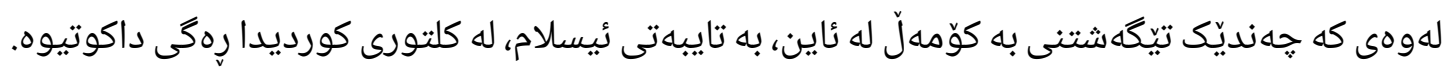

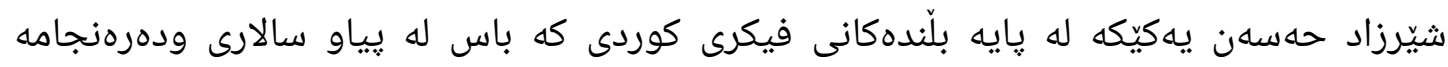

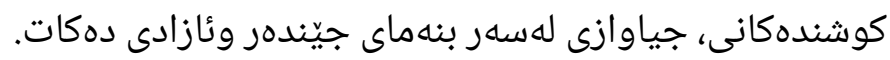




\section{QALAAI ZANISTSCIENTIFIC JOURNAL}

A Scientific Quarterly Refereed Journal Issued by Lebanese French University - Erbil, Kurdistan, Iraq

Vol. (6), No (4), Autumn 2021

ISSN 2518-6566 (Online) - ISSN 2518-6558 (Print)

\section{الأبوية في أعمال مختارة لشيرزاد حسن؛ القلعة وكلاب أبي، امرأة على مئذنة وسهل الغزال المذبوح}

الملخص:

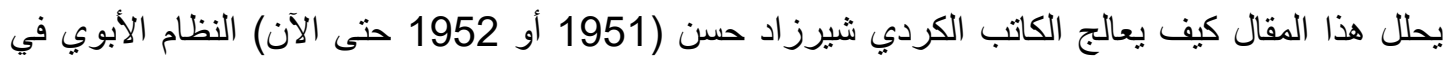

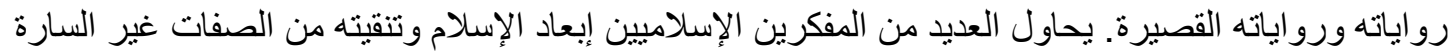

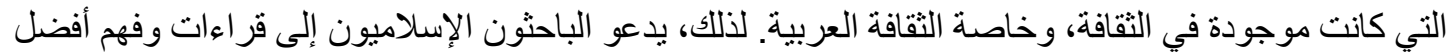

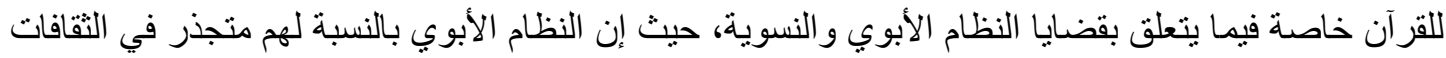

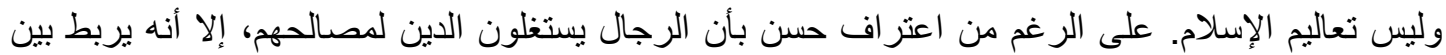



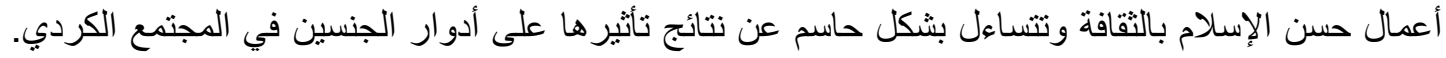

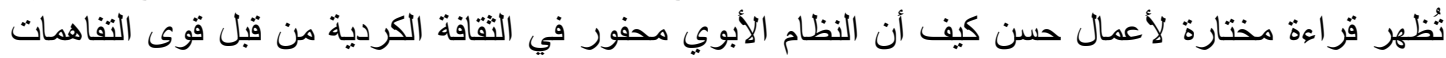

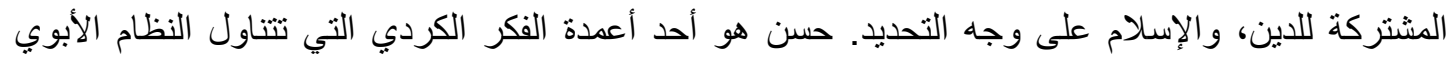
و عو اقبه الوخيمة و عدم المساواة بين الجنسين و الحرية. 